\title{
The Effect of Empowerment Program on the Development of Scavenger's Welfare at Mancani Trash Centre in Palopo District the Province of South Sulawesi
}

\author{
Muh. Yusuf Qamaruddin \\ STIE Muhammadiyah Palopo, South Sulawesi, Indonesia \\ myqstie@yahoo.co.id
}

\begin{abstract}
This study aims to see The Effect of Empowerment Program on The Development of Scavenger's Welfare at Mancani Trash Centre in Palopo District the Province of South Sulawesi. Data analysis method applied in the study was quantitative analysis using Simple Linear Regression involving two variables. The results from analysis of the effect of empowerment program on the development of scavenger's welfare at Mancani trash centre in Palopo the province of south Sulawesi presented in table 4.4 showed R-value of 0.684 reflected that there is positive and significant relationship between the program and the development of scavenger's welfare. From these results, double determinant coefficient value $\left(\mathrm{R}^{2}\right)$ of 0.467 implied that Xvariable, which is the program itself, contributed of $46.7 \%$ on the development of scavenger's welfare. The rest of $53.3 \%$ was influenced by other factors.
\end{abstract}

Keywords: Empowerment, Scavenge, Welfare, Palopo

\section{Introduction}

Background: The rapid growth of science and technology in many fields are followed by the changes of paradigm on national development based on human resource views as both subject and object of such nation development. Economic development of such region/area highly depends both on its natural and human resources as well as the ability to manage those resources. Therefore, the local government of Palopo in the province of South Sulawesi keeps developing their regional resources through policies and decision-making as well as take some strategic steps then to be actualized in the form of recent development. Workforce is an essential aspect in the economic development since it is one of payback of production factor. Recently, the issues of both job opportunity and economic development either in national or regional level received high attention in the public. From the recapitulation of Social and Labour Agency of Palopo known that 1.390 of 5.676 new job seekers are male and rest, 2.286 are female. According to data on education background level it could be concluded that these new job seekers were highly competent because 1.206 of those who were succeed in getting their job, 36.07 percents were in bachelor degree, 61.61 percents were in high school to diploma degree, and the other 2.33 were in primary to junior high school degree. This is good enough if they are empowered according to their own skills and preferences. Economically, activities of the scavenger have an excellent prospect to be developed. This group of society never create some troubles for their environment, contrarily, clean the environment up by collecting inorganic trashes that treat the ecosystem of natural environment.

Problem Formulation: From the background above, the problem could be formulated as follows: "How is the effect of The Effect of Empowerment Program on The Development of Scavenger's Welfare at Mancani Trash Centre in Palopo District the Province of South Sulawesi".

\section{Literature Review}

The Meaning of Social Empowerment: Social empowerment is such efforts to empower the society in order to make them to have a power to live on their own. These efforts including to growth the consciousness, willingness and ability to increase their welfare accompanied with supporting climate development. These efforts are performed together from, by and for the society according to the condition, problem and potency of such area. Thus, social empowerment is a process while both self-reliance of the society and welfare development are the output. (Depkes, 2006:8). Sumodiningrat (2007:29) claimed empowerment as an alternative concept of development stressed the autonomy of social group taken based on personal resources, 
participation, democracy and social learning through personal experiences. The focus is on locality, since civil society is more empowered by local issues. However, Friedman reminded that it is unrealistic to ignored economic power and structures outside the civil society. Therefore, social empowerment is not limited in economic area but political as well so that the society has bargaining power in both national and international level. As the anti-thesis of development above, bottom-direction development strategy viewed that such development should be based on, particularly, the full mobilization of human, natural and department resources in the orientation of the fulfilment of basic needs of the people in related area. Furthermore, it oriented to basic needs, the empowerment of small-scale industries, local natural resources, and village and tends to utilize such efficient technology rather than high technology.

The Meaning of Welfare: Etymologically, welfare means the feeling of safe, prosperous, wealth and wellbeing (Yuwono and Abdullah, 1994:368). It always related with such a condition or level of life that become a dream, hope and the expectation of everyone, family and even in society and national level. It always becomes the goal of everyone and group of society either they pursue it by their own or together with another so that all of the activities and thoughts in their daily life were directed to the question on how to achieve this condition of life. In short, from the explanation above it could be says that, in essential, welfare is such a highvalue condition in the level of life that human expected. So far there is no appropriate concept generated on welfare family. Often, it merely interpreted in economic sense. The meaning of welfare itself is such condition where the basic needs, either as consumer or other material needs are fulfilled so that individual needs no worry with his/her own life (Suyono, 1996:43).

General Review on Scavenger: Scavenger is individual who picked commercial value-contained garbage in such area including in trash box, on the street, at ditches and anywhere they can found it. According to Main Dictionary of Indonesian, scavenger is individual who, in order to fulfil their needs of life, pick up and collect waste and trash to be used as material raw in production process and so on. They are person who looking after, picked-up and utilize recyclable trashes by sell it to someone who will recycling it into a new commodity (KBBI, Depdikbud, 2002).

\section{Methodology}

Location: The study was held in Mancani Trash Centre in Telluwanua, Palopo in the Province of South Sulawesi. The location was chosen since the group of scavenger who lived together was found here so it was expected will make the study easier.

\section{Data Collecting Method}

- Questionnaire, by spreading such a list of enclosed-question contains alternative answers for each question given.

- Interview, by directly asking some questions to the respondent in order to get a clear understanding about the question given.

- Observation, by observing the activity of the scavenger in direct ways.

- Documental review, by learning several sources including books, journals, documents, reports and laws and rules related to the variable of the study.

Analysis Method: Data analysis method used in the study was quantitative analysis using Simple Linear Regression involving two variables, Y-dependent variable and X-independent variable (Hasan, 2002:15) with the formulation as follows:

$$
Y=\alpha+b X
$$

Where:

$\mathrm{Y} \quad=$ variable of criteria

$\mathrm{X}=$ variable of predictor

a $\quad=$ constant number

$\mathrm{b}=$ = the coefficient of regression, indicating increasing or decreasing number of dependent variable based on independent variable 


\section{Analysis and Discussion}

The description of Scavenger's Empowerment Variable and Score Calculation. In order to know responses of the respondent on the indicator as well as score calculation for the variable of scavenger's empowerment divided into three indicators, including planning, application and self-reliance/followed-up, it could be seen in table 1 as follows:

Table 1: Response of the respondent on the variable of scavenger's empowerment $(X)$

\begin{tabular}{|c|c|c|c|c|c|c|c|c|c|c|c|}
\hline \multirow{3}{*}{$\begin{array}{l}\text { Nmbr. of } \\
\text { quest. }\end{array}$} & \multicolumn{10}{|c|}{ Response level of the respondent } & \multirow{3}{*}{$\begin{array}{l}\text { Score } \\
\text { calc. }\end{array}$} \\
\hline & \multirow{2}{*}{$\begin{array}{l}\mathbf{1} \\
\mathbf{F}\end{array}$} & & \multirow[t]{2}{*}{2} & & \multirow{2}{*}{$\begin{array}{l}3 \\
\% \\
\end{array}$} & & \multirow{2}{*}{$\begin{array}{l}4 \\
\text { F }\end{array}$} & \multirow[b]{2}{*}{$\%$} & \multirow[t]{2}{*}{5} & \multirow[b]{2}{*}{$\mathbf{F}$} & \\
\hline & & $\%$ & & $\mathbf{F}$ & & & & & & & \\
\hline 1 & - & - & - & - & 6 & 25,0 & 8 & 33,3 & 10 & 41,7 & 100 \\
\hline 2 & 5 & 20,8 & 12 & 50,0 & 5 & 20,8 & 2 & 8,3 & - & - & 52 \\
\hline 3 & 3 & 12,5 & 3 & 12,5 & 3 & 12,5 & 9 & 37,5 & 6 & 25,0 & 84 \\
\hline 4 & 1 & 4,2 & 5 & 20,8 & 5 & 20,8 & 7 & 29,2 & 6 & 25,0 & 84 \\
\hline 5 & - & - & - & - & 3 & 12,5 & 12 & 50,0 & 9 & 37,5 & 102 \\
\hline 6 & - & - & 3 & 12,5 & 7 & 29,2 & 11 & 45,8 & 3 & 12,5 & 86 \\
\hline 7 & 3 & 12,5 & 3 & 12,5 & 7 & 29,2 & 10 & 41,7 & 1 & 4,2 & 75 \\
\hline 8 & - & - & - & - & 3 & 12,5 & 18 & 75,0 & 3 & 12,5 & 96 \\
\hline 9 & - & - & - & - & 7 & 29,2 & 11 & 45,8 & 6 & 25,0 & 95 \\
\hline 10 & 6 & 25,0 & 13 & 54,2 & 5 & 20,8 & - & - & - & - & 47 \\
\hline 11 & - & - & - & - & 2 & 8,3 & 14 & 58,3 & 8 & 33,3 & 102 \\
\hline 12 & - & - & - & - & 7 & 29,2 & 11 & 45,8 & 6 & 25,0 & 95 \\
\hline 13 & - & - & 1 & 4,2 & 6 & 25,0 & 16 & 66,7 & 1 & 4,2 & 89 \\
\hline 14 & - & - & - & - & 9 & 37,5 & 13 & 54,2 & 2 & 8,3 & 89 \\
\hline 15 & 4 & 16,7 & 6 & 25,0 & 3 & 12,5 & 7 & 29,2 & 4 & 16,7 & 73 \\
\hline 16 & - & - & 1 & 4,2 & 10 & 41,7 & 7 & 29,2 & 6 & 25,0 & 90 \\
\hline 17 & 6 & 25,0 & 13 & 54,2 & 4 & 16,7 & 1 & 4,2 & - & - & 48 \\
\hline 18 & - & - & - & - & 1 & 4,2 & 20 & 83,3 & 3 & 12,5 & 98 \\
\hline 19 & - & - & 1 & 4,2 & 7 & 29,2 & 12 & 50,0 & 4 & 16,7 & 91 \\
\hline 20 & - & - & - & - & 4 & 16,7 & 17 & 70,8 & 3 & 12,5 & 95 \\
\hline 21 & - & - & 1 & 4,2 & 7 & 29,2 & 12 & 50,0 & 4 & 16,7 & 91 \\
\hline \multicolumn{11}{|c|}{ Mean value of the question } & 84,86 \\
\hline \multicolumn{11}{|c|}{ Mean value divided by number of respondents } & 3,54 \\
\hline
\end{tabular}

Source: Post-processed Primary Data, 2014

According to the table above, some responses of the respondents on the variable could be explained then as follows:

- On the first question, 6 respondents (25\%) were response with agree-enough, 8 respondents (33.3\%) were agree and 10 respondents $(41.7 \%)$ were very agree.

- On the second question, 2 respondents (8.3\%) were response with agree, 5 respondents (20.8\%) were agree-enough 12 respondents (50\%) were less-agree and 5 respondents (20.8\%) were disagree.

- On the third question, 3 respondents (12.5\%) were response with always absent, 3 respondents $(12.5 \%)$ were less often, 3 respondents $(12.5 \%)$ were quite often, 9 respondents were often and 6 respondents $(25 \%)$ were very often.

- On the fourth question, 1 respondent (4.2\%) were always absent, 5 respondents $(20.8 \%)$ were just presence, 5 respondents $(20.8 \%)$ were presence and asking some question, 7 respondents $(29.2 \%)$ were presence, asking some question and give some opinion and 6 respondents (25\%) were presence, asked question, give opinion and have some acceptable opinion.

- On the fifth question, 3 respondents (12.5\%) were response quite fair, 12 respondents (50\%) were fair and 9 respondents (37.5\%) were very fair.

- $\quad$ On the sixth question, 3 respondents $(12.5 \%)$ were response with less agree, 7 respondents $(29.2 \%)$ were quite agree, 11 respondents $(45.8 \%)$ were agree and 3 respondents $(12.5 \%)$ were very agree.

- On the seventh question, 3 respondents $(12.5 \%)$ were always absent, 3 respondents $(12.5 \%)$ were less frequent, 7 respondents (29.2\%) were quite often, 10 respondents (41.7\%) were often and 1 respondent $(4,2 \%)$ were very often. 
- On the eighth question, 3 respondents (12.5\%) were response with quite fair, 18 respondents (75\%) were fair and 3 respondents (12.5\%) were very fair.

- On the ninth question, 7 respondents $(29.2 \%)$ were response with agree-enough, 11 respondents $(45.8 \%)$ were agree and 6 respondents $(25 \%)$ were very agree.

- On the tenth question, 6 respondents (25\%) were response with disagree, 13 respondents (54.2\%) were less agree and 5 respondents (20.8\%) were very agree.

- On the eleventh question, 2 respondents (8.3\%) were response with agree-enough, 14 respondents (58.3\%) were agree and 8 respondents (33.3\%) were very agree.

- On the twelfth question, 7 respondents (29.2\%) were response with agree-enough, 11 respondents $(45,8 \%)$ were agree and 6 respondents $(25 \%)$ were very agree.

- On the thirteenth question, 1 respondent (4.2\%) were response with less agree, 6 respondents (25\%) were agree-enough, 16 respondents (66.7\%) were agree and 1 respondent $(4.2 \%)$ were very agree.

- On the fourteenth question, 9 respondents (37.5\%) were response with agree-enough, 13 respondents (54.2\%) were agree and 2 respondents (8.3\%) were very agree.

- On the fifteenth question, 4 respondents $(16.7 \%)$ were always absent, 6 respondents $(25 \%)$ were less frequent, 3 respondents $(12.5 \%)$ were quite often, 7 respondents $(29.2 \%)$ were often and 4 respondents $(16.7 \%)$ were very often.

- On the sixteenth question, 1 respondent (4.2\%) were response with less agree, 10 respondents $(41.7 \%)$ were agree-enough, 7 respondents $(29.2 \%)$ were agree and 6 respondents $(25 \%)$ were very agree.

- On the seventeenth question, 6 respondents (25\%) were response with disagree, 13 respondents $(54.2 \%)$ were less agree, 4 respondents $(16.7 \%)$ were quite agree and 1 respondent $(4.2 \%)$ were agree.

- On the eighteenth question, 1 respondent (4.2\%) were response with agree-enough, 20 respondents $(83,3 \%)$ were agree and 3 respondents $(12.5 \%)$ were very agree.

- On the nineteenth question, 1 respondent (4.2\%) were response with less agree, 7 respondents $(29.2 \%)$ were quite, 12 respondents (50\%) were agree and 4 respondents $(16.7 \%)$ were very agree.

- On the twentieth question, 4 respondents (16.7\%) were response with agree-enough, 17 respondents $(70.8 \%)$ were agree and 3 respondents $(12.5 \%)$ were very agree.

- On the twenty first question, 1 respondent (4.2\%) were response with less agree, 7 respondents $(29.2 \%)$ were quite agree, 12 respondents $(50 \%)$ were agree and 4 respondents $(16,7 \%)$ were very agree.

The description of Higher Income Variable and Score Calculation: Indicator of the variable is divided into eight (8) indicators of questions, presented as follows in table 2:

Table 2: Response of the respondent on Higher Level of Welfare Variable in Mancani Trash Centre at Palopo (Y)

\begin{tabular}{|c|c|c|c|c|c|c|c|c|c|c|c|}
\hline \multirow{3}{*}{$\begin{array}{l}\text { Nmbr. of } \\
\text { quest. }\end{array}$} & \multicolumn{10}{|c|}{ Response level of the respondent } & \multirow{3}{*}{$\begin{array}{l}\text { Score } \\
\text { calc. }\end{array}$} \\
\hline & 1 & & 2 & & 3 & & 4 & & 5 & & \\
\hline & $\mathbf{F}$ & $\%$ & $\mathbf{F}$ & $\%$ & $\mathbf{F}$ & $\%$ & $\mathbf{F}$ & $\%$ & $\mathbf{F}$ & $\%$ & \\
\hline 1 & - & - & - & - & 3 & 12,5 & 8 & 33,3 & 13 & 54.2 & 106 \\
\hline 2 & 6 & 25,0 & 15 & 62.5 & 3 & 12.5 & - & - & - & - & 45 \\
\hline 3 & 1 & 4,2 & 6 & 25.0 & 11 & 45.8 & 5 & 20.8 & 1 & 4.2 & 71 \\
\hline 4 & - & - & 6 & 25.0 & 16 & 66.7 & 2 & 8.3 & - & - & 68 \\
\hline 5 & - & - & 4 & 16.7 & 6 & 25.0 & 12 & 50.0 & 2 & 8.3 & 84 \\
\hline 6 & 9 & 37,5 & 13 & 54.2 & 2 & 8.3 & - & - & - & - & 41 \\
\hline 7 & - & - & 1 & 4.2 & 7 & 29.2 & 15 & 62.5 & 1 & 4.2 & 88 \\
\hline 8 & - & - & 1 & 4.2 & - & - & 9 & 37.5 & 14 & 58.3 & 108 \\
\hline \multicolumn{11}{|c|}{ Mean value of the question } & 76.38 \\
\hline \multicolumn{11}{|c|}{ Mean value divided by number of respondents } & 3.18 \\
\hline
\end{tabular}

Source: Post-processed Primary Data, 2014 
According to the table above, some responses of the respondents on the variable could be explained then as follows:

- On the first question, 3 respondents (12.5\%) were response with agree-enough, 8 respondents $(33,3 \%)$ were agree and 13 respondents $(54,2 \%)$ were very agree.

- $\quad$ On the second question, 6 respondents (25\%) were response with disagree, 15 respondents $(62.5 \%)$ were less agree and 3 respondents (12.5\%) were quite agree.

- On the third question, 1 respondent (4.2\%) were response with disagree, 6 respondents (25\%) were less agree, 11 respondents $(45.8 \%)$ were quite agree, 5 respondents $(20.8 \%)$ were agree and 1 respondent $(4,2 \%)$ were very agree.

- On the fourth question, 6 respondents (25\%) were response with less agrees, 16 respondents $(66.7 \%)$ were quite agree and 2 respondents $(8.3 \%)$ were agree.

- $\quad$ On the fifth question, 4 respondents (16.7\%) were response with less agree, 6 respondents (25\%) were quite agree, 12 respondents (50\%) were agree and 2 respondents $(8.3 \%)$ were very agree.

- On the sixth question, 9 respondents (37.5\%) were response with disagree, 13 respondents (54.2\%) were lack agree and 2 respondents $(8.3 \%)$ were very agree.

- On the seventh question, 1 respondent (4.2\%) were response with less agree, 7 respondents (29.2\%) were quite agree, 15 respondents (62.5\%) were agree and 1 respondent (4.2\%) were very agree.

- On the eight questions, 1 respondent (4.2\%) were response with less agree, 9 respondents (37.5\%) were agree and 14 respondents (58.3\%) were very agree.

From those results it could be concluded that the increasing of welfare level among the scavenger in Mancani Trash Centre at Palopo in the Province of South Sulawesi after the introduction of the program was of 3.18 or in third range, middle level.

Simple Regression: In order to analyse variables used in the study, simple regression method was applied resulting regression coefficient of X-variable (empowerment program) which have effect on Y-variable (the increasing of welfare level). Based on the analyses using SPSS program, regression of the analyses was resulted as follows:

Table 3: The effect of the program on the increasing level of welfare among the scavenger in Mancani Trash Centre at Palopo Coefficients (a)

\begin{tabular}{lllllll}
\hline & & \multicolumn{2}{l}{$\begin{array}{l}\text { Unstandardized } \\
\text { coefficients } \\
\text { Model }\end{array}$} & $\begin{array}{l}\text { Standardized } \\
\text { coefficients } \\
\text { Beta }\end{array}$ & $\begin{array}{l}\text { T } \\
\text { B }\end{array}$ & $\begin{array}{l}\text { Sig. } \\
\text { Std. Error }\end{array}$ \\
\hline & & 1.175 & .460 & & 2.555 & .018 \\
& $\begin{array}{l}\text { (Constant) } \\
\begin{array}{l}\text { Empowerment } \\
\text { Education } \\
\text { Health }\end{array}\end{array}$ & .568 & .129 & .684 & 4.393 & .000 \\
\hline
\end{tabular}

a Dependent Variable: The increasing of welfare

Source: Post-processed Primary Data, 2014

From the coefficient value in table 4.3 above, the equation of simple regression could be formulized then as follows: $\mathrm{Y}=1.175+0.568 \mathrm{X}$

Where:

$\mathrm{a}=\quad 1.175$, which means of this value indicate the increasing level of welfare only if the factor of program $(\mathrm{X})$ itself was ignored

$\mathrm{b}=\quad 0.568$, which means if this value is about to be added by 1 point then the increasing level of welfare will be higher as of 0.568

The regression results in table 3 above showed that factor of empowerment $(\mathrm{X})$ positively impacts on the increasing level of welfare $(\mathrm{Y})$. Next, in order to figure out the relationship between the program and the increasing level of welfare, we can count it down using Correlation and Determination Coefficients. Based on the analysis results using SPSS program, the analysis results were obtained as follows: 
Table 4: Correlation and Determination Coefficients

\begin{tabular}{lllll}
\hline Model & $\mathbf{R}$ & R-Square & $\begin{array}{l}\text { Adjusted } \\
\text { R-Square }\end{array}$ & $\begin{array}{l}\text { Std. Error of the } \\
\text { Estimate }\end{array}$ \\
\hline 1 & $.648(\mathrm{a})$ & .467 & .443 & .22472 \\
\hline
\end{tabular}

a Predictors: (Constant), empowerment in education, BLM and health

b Dependent variable: the increasing level of welfare

Source: Post-processed Primary Data, 2014

Results of the analysis in the table 4.4 above shows $\mathrm{R}$-value $=0.684$ reflecting that there is a positive and significant relationship between the program and the increasing level of welfare. From these results, double determination coefficient value $\left(\mathrm{R}^{2}\right)$ was 0.467 which means $\mathrm{X}$-variable contributed to the increasing level of welfare as of $46.7 \%$. Meanwhile, $53.3 \%$ of the rest were influenced by other factors.

The examination on the results of regression analysis: In order to test the hypothesis resulted, t-test was used to know significance level of regression coefficient of independent variable and to make sure whether independent variable (the program itself) in the equation have significant effect on dependent variable (the increasing level of welfare). The test was performed by comparing the value of $t_{\text {table }}$ and $t_{\text {count }}$. If the former is lower, then the alternative hypothesis stated that such independent variable have effects on dependent one, unacceptable.

Hypothetical test:

In the statistical hypothesis, stated as follows:

$\mathrm{H}_{0}=\mathrm{t}_{\text {count }} \leq \mathrm{t}_{\text {table, }}$, means that there is no effect of the program on the increasing level of welfare

$\mathrm{H}_{1}=\quad \mathrm{t}_{\text {count }}>\mathrm{t}_{\text {table, }}$ means that there is positive effect of the program on the increasing level of welfare

Based on the analysis results using SPSS program, the analysis results were obtained as follows. The value of $\mathrm{t}_{\text {count }}$ according to table 16 was 2.555. Meanwhile, the value in distribution 5-table was 2.052. Then, $\mathrm{t}_{\text {count }}$ $(2.555)>t_{\text {table }}(2.052)$. It means that the program (X) has positive effect on the increasing level of welfare. It strengthens by significance level of $0.018<0.05$, which means that the program $(\mathrm{X})$ has significant effect on the increasing level of welfare. Then, it could be concluded that $\mathrm{H}_{1}$ acceptable.

\section{Conclusion}

Based on the discussion of the study outlined above, then in this section, the writer would like to formulize some conclusions of the results obtained:

- From the equation of Simple Linear Regression where $\mathrm{Y}=1.175+0.568 \mathrm{X}$ was a positive value showing that the program was succeed in the increasing level of welfare among the scavenger at Mancani Trash Centre in Palopo.

- That the program gives contribution of $46.7 \%$ on the increasing level of welfare obtained from the coefficient value of determination of 0.467 multiplied with $100 \%$ while the rest $(53.3 \%)$ was influenced by other factors. It shows that the program give middle effect on the increasing level of welfare.

- Based on both analysis and evaluation performed, it concluded that the program should be done continuously and actively involving the scavenger itself in order to make it have positive and significant effect on the increasing level of welfare in the future.

- Based on both analysis and evaluation performed, it concluded that the program should be studied well since the obtained results were in middle level. 


\section{References}

Depdikbud. (2002). Kamus Besar Bahasa Indonesia (KBBI)., Balai Pustaka, Jakarta.

Depkes, R. I. (2006). Penggerakan dan Pemberdayaan Masyarakat Melalui Kemitraan. Jakarta.

Hasan, I. (2002). Pokok-pokok Materi Metodologi Penelitian dan Aplikasinya, Ghalia Indonesia, Jakarta.

Suyono, H. S. (1996). Peningkatan Kualitas dan Kesejahteraan Keluarga Melalui Pendidikan dan Pemberdayaan Masyarakat. BKKBN Pusat. Jakarta.

Sumodiningrat, G. (2007). Pemberdayaan Sosial, Kompas Media Nusantara, Jakarta.

Yuwono, T. \& Abdullah, P. (1994). Kamus Lengkap Bahasa Indonesia. Praktis Arkola. Surabaya. 